KENOSIS : JURNAL KAJIAN TEOLOGI

ISSN 2460-6901(Print), 2656-4483 (Online)

https://e-journal.iaknambon.ac.id/index.php/KNS

DOI: 10.37196/kenosis.v1i1.279

\title{
MENGAKU ALLAH, MERUPA DALAM KONTEKS: Tinjauan Historis terhadap Pengakuan Iman Gereja-Gereja di Indonesia
}

\section{Christanto Sema Rappan Paledung dan Alfa Kristian Hia}

\author{
Fakultas Teologi \\ Universitas Kristen Indonesia Toraja \\ Jalan Nusantara No. 12 Makale Tana Toraja, Sulawesi Selatan \\ rappanpaledung@gmail.com \\ alfakristianhia@gmail.com
}

\begin{abstract}
This study is a historical description of the struggles of the churches in Indonesia on the relevance of the profession of faith to the context of their presence. This description focuses on some of these local churches in Indonesia, namely the Toraja Church, the Indonesian Christian Church, The Batak Christian Protestant Church, and the Javanese Christian Churches. These churches were born from the womb of zending which made them use the confession of faith from his predecessor church. However, the struggle with the context makes these churches have to formulate the confession of faith with awareness of the context. This paper explores these struggles using a historical approach. At the end, we will compare it with the Common Confession of Christian Faith formulated by the Communion of Churches in Indonesia. Our main argument is that the confession of faith of a church is a form of its struggle with the tradition in which it stands with the context of its presence.
\end{abstract}

Keywords: Confession, context, Toraja Church, Indonesian Christian Church, Batak Christian Protestant Church, Javanese Christian Churches, Common Confession of Christian Faith

\begin{abstract}
Abstrak
Studi ini merupakan uraian historis mengenai pergulatan gereja-gereja di Indonesia terhadap relevansi pengakuan iman dengan konteks kehadirannya. Uraian ini berfokus kepada beberapa gereja lokal ini Indonesia, yakni Gereja Toraja, Gereja Kristen Indonesia, Huria Kristen Batak Protestan, dan Gereja-gereja Kristen Jawa. Gereja-gereja tersebut lahir dari rahim zending yang membuatnya menggunakan pengakuan iman dari gereja pendahulunya. Namun, pergulatan dengan konteksnya membuat gereja-gereja tersebut harus merumuskan pengakuan iman dengan kesadaran konteksnya. Studi ini menelusuri pergulatan tersebut
\end{abstract}


dengan menggunakan pendekatan historis. Pada bagian akhir, kami akan membandingkannya dengan Pengakuan Bersama Iman Kristen yang dirumuskan Persekutuan Gereja-gereja di Indonesia. Argumen utama tulisan ini adalah bahwa pengakuan iman sebuah gereja merupakan wujud pergulatannya dengan tradisi di mana ia berpijak dengan konteks kehadirannya.

Kata Kunci: Pengakuan Iman, Konteks, Gereja Toraja, Gereja Kristen Indonesia, Huria Kristen Batak Protestan, Gereja-gereja Kristen Jawa, Pengakuan Bersama Iman Kristen

\section{PENDAHULUAN}

Pengakuan iman dalam ibadah Kristen sebenarnya merupakan jawaban umat atas Firman Allah yang telah diberitakan, berupa pernyataan, selain dapat berupa doa dan nyanyian. Sebagian besar gereja dan orang Kristen di Indonesia masih menganggap bahwa pengakuan iman yang biasa diucapkan dalam ibadah merupakan warisan dari badan pengabaran Injil. Kita dapat menemukan pengakuan semacam ini dalam bentuk Pengakuan Iman Rasuli, Pengakuan Athanasius, dan Pengakuan Iman Nicea-Konstantinopel. Pengakuan-pengakuan tersebut lahir dalam situasi dan konteks kehidupan umat pada masa kekristenan mula-mula.

Dengan demikian, pengakuan-pengakuan iman ini merupakan jawaban umat atas Firman Allah yang mereka dengar dalam konteks pergumulan saat itu. Meskipun nilai teologis dalam pengakuan-pengakuan ini sangat dalam, tetapi apakah pengakuan yang telah melewati berbagai zaman ini merupakan jawaban yang murni dari umat Kristen saat ini? Sejak abad ke-20, sejumlah gereja di Indonesia yang telah menyusun pengakuan imannya dalam kaitannya dengan pengakuan dan tradisi gereja sebelumnya serta dengan memerhatikan relevansi konteksnya. ${ }^{1}$ Dalam tulisan ini, peneliti akan memaparkan bagaimana gereja-gereja di Indonesia bergulat dengan konteks kehadirannya sehingga melahirkan pengakuan iman. Kami akan membatasinya pada beberapa gereja Protestan Indonesia, yakni Gereja Toraja, Gereja Kristen Indonesia, Huria Kristen Batak Protestan, dan Gereja-gereja Kristen Jawa, serta hubungannya dengan Pengakuan Bersama Iman Kristen yang ditetapkan oleh Persekutuan Gereja-gereja di Indonesia (PGI).

Sebelumnya, beberapa penulis telah melakukan riset terhadap pengakuan iman. Misalnya, Radius Aditya Jonar, dalam Teologis atau Politis?, melakukan riset 
mengenai latar belakang historis dari pengakuan iman Nicea-Konstantinopel. Menurutnya, pengakuan tersebut kerap kali dipahami sebagai hasil dari pergulatan teologis Bapa-bapa Gereja. Namun, Jonar menemukan bahwa pemahaman terhadap pengakuan mengabaikan adanya faktor politik kekuasaan dalam perumusannya. Keduanya, teologis dan politis, berkelit-kelindan dalam proses perumusannya. ${ }^{2}$ Penulis lainnya, Ebenhaizer Nuban Timo, dalam Gereja Merumuskan Jawab, mengulas bagaimana pengakuan iman gereja di sepanjang masa dirumuskan dengan kesadaran mengenai persoalan-persoalan sosial. Sayangnya, respons gereja terhadap keadaan sosial gereja di Indonesia, khususnya Nusa Tenggara Timur, tidak memberi pegangan dan jawaban bagi umat. ${ }^{3}$ Jonar dan Timo sama-sama menegaskan bahwa ada kesadaran konteks yang melatarbelakangi perumusan pengakuan iman. Sebab itu, kami melihat bahwa beberapa gereja di Indonesia merumuskan pengakuannya dalam dan dengan kesadaran konteksnya.

Argumen utama kami adalah bahwa pengakuan iman sebuah gereja merupakan wujud pergulatannya dengan tradisi di mana ia berasal dan juga dengan kesadaran akan konteks kehadirannya. Dengan demikian, kami membagi makalah ini akan menjadi empat bagian. Bagian pertama akan memaparkan bagaimana dokumen pengakuan iman pada masa Reformasi yang umumnya dibawa oleh para zending ke Indonesia dan digunakan hingga pada waktu tertentu. Dokumen-dokumen tersebut adalah Confessio Augsburg, ${ }^{4}$ Buku Konkord, ${ }^{5}$ Katekismus Heidelberg, ${ }^{6}$ dan Pasalpasal Ajaran Dordrecht. ${ }^{7}$ Dokumen-dokumen inilah yang mewarnai teologi gerejagereja Indonesia setidaknya hingga masing-masing merumuskan pengakuannya sendiri. Bagian kedua akan menjabarkan bagaimana kemudian gereja-gereja di Indonesia bergumul dengan konteksnya masing-masing hingga kemudian merumuskan pengakuan iman yang relevan dengan konteksnya. Pada bagian inilah kami akan menjabarkan proses perumusan pengakuan iman Gereja Toraja, Gereja Kristen Indonesia, Gereja-gereja Kristen Jawa, dan Huria Kristen Batak Protestan. Bagian ketiga akan menjabarkan Pengakuan Bersama Iman Kristen dari PGI sebagai bentuk kesatuan gereja-gereja tersebut di atas. Bagian terakhir kami akan menandaskan bagaimana pentingnya pengakuan iman untuk menegaskan relevansi iman Kristen dengan konteks partikular sekaligus konteks yang lebih luas. 


\section{METODE PENELITIAN}

Artikel ini akan menggunakan penelitian kepustakaan (library research), yaitu mengumpulkan dan mempelajari data-data kepustakaan seperti buku-buku dan jurnaljurnal. Proses ini meliputi penelusuran terhadap sejarah perumusan pengakuan iman di gereja-gereja tersebut di atas, dan latar kesadaran konteks yang memengaruhinya. Pendekatan artikel dititikberatkan pada pendekatan historis.

\section{HASIL DAN PEMBAHASAN}

\section{Dokumen Pengakuan Iman pada Masa Reformasi}

Pada masa Reformasi, pengakuan-pengakuan yang dirumuskan oleh para reformator bertujuan untuk menentang kesesatan-kesesatan, khususnya yang terjadi di kalangan Gereja Katolik Roma. Dua reformator yang menonjol pada masa ini dalam merumuskan pengakuan iman Kristen adalah Martin Luther (1483-1546) dan John Calvin (1509-1564). Jacob P. D. Groen, dalam Terpanggil Untuk Mengakui Iman (2012), ${ }^{8}$ mengungkapkan bahwa tujuan Reformasi kala itu sebenarnya bukan untuk mendirikan gereja baru, melainkan untuk memulihkan kembali keadaan gereja yang sudah merosot. ${ }^{9}$ Baik Luther maupun Calvin lebih menekankan pendidikan ajaran Alkitab atau pendidikan iman Kristen kepada seluruh anggota gereja. Hal inilah yang tampak dalam beberapa ajaran dan katekismus yang dihasilkan pada masa Reformasi, antara lain: Confessio Augsburg, Buku Konkord, Katekismus Heidelberg, dan Pasalpasal Ajaran Dordrecht.

\section{Confessio Augustana (Konfesi Augsburg)}

Sebelum pengakuan (confessio) Augsburg dideklarasikan, Martin Luther telah menghasilkan Katekismus Besar dan Katekismus Kecil pada tahun 1529. Groen menjelaskan bahwa Katekismus Luther bertujuan untuk membangun pengetahuan anggota gereja. Dalam katekismus tersebut, Luther secara berurutan membahas: Kesepuluh Firman (I); dua belas pasal Symbolum Apostolicum (II); Doa Bapa Kami (III), Pembaptisan (IV); Pengakuan Dosa (V); Perjamuan Kudus (VI); doa pagi dan malam (VII), dan doa sebelum dan sesudah makan (VIII). ${ }^{10}$ Dua katekismus tersebut memengaruhi gereja-gereja Lutheran sehingga keduanya diterima sebagai pengakuan 
yang resmi dan pada akhirnya dimasukkan ke dalam pengakuan gereja-gereja Lutheran di dalam Buku Konkord pada tahun $1580 .^{11}$

Di saat kaum Protestan mendapatkan perlawanan dari kaisar dan Gereja Katolik Roma, tokoh-tokoh pada masa Reformasi mengalami perpecahan di antara mereka sendiri. Hal ini terjadi di masa pemerintahan raja di Spanyol, Karel V (15001558). Ia melarang segala ibadat kaum Protestan dan menolak aliran Protestan yang dibawa oleh para reformator kala itu. Dipelopori oleh Philippus Melanchton (14971560), Pengakuan Augsburg lahir untuk menanggapi penolakan terhadap kaum Prostestan. Berdasarkan isi dan pembagiannya, Pengakuan Augsburg (1530) bertujuan untuk membela kaum Protestan dari tuduhan bahwa mereka memecah gereja dan membahayakan kesatuan negara. ${ }^{12}$ Di dalam pengakuan tersebut, doktrin Protestan secara jelas mengutuk para bidat, orang Donatis dan menolak agama Islam dan ajaran Yahudi yang dianggap tidak sesuai dengan pemahaman iman Kristen.

Ada beberapa hal penting yang terdapat di dalam Pengakuan Augsburg. Pertama, sebagai upaya untuk tetap mempertahankan pandangan bahwa Reformasi tidak membawa suatu ajaran baru, maka Pengakuan Augsburg sering mengutip Bapabapa Gereja, misalnya Augustinus dan Ambrosius, yang juga dihormati oleh Gereja Katolik Roma. Kedua, Pengakuan Augsburg dimulai dengan menyatakan iman kepada Allah Tritunggal: Bapa, Anak (Yesus Kristus), dan Roh Kudus. ${ }^{13}$ Hal ini bertujuan agar anggota jemaat dapat memahami dengan benar ketritunggalan tersebut. Ketiga, Pengakuan Augsburg tidak hanya menjelaskan Sola Scriptura (hanya Kitab Suci yang berisi Firman Tuhan), tetapi juga pengakuan Sola Fide (hanya oleh iman) dan Sola Gratia (hanya oleh rahmat), seperti yang diutarakan oleh Luther. ${ }^{14}$ Dengan demikian, Melanchton melalui Pengakuan Augsburg sebenarnya hendak mengembalikan ajaran gereja kepada Kitab Suci dan menolak segala kesesatan ajaran serta upacara yang ada di dalam gereja pada masa itu.

\section{Buku Konkord}

Para pengikut Luther saling bertikai secara teologi setelah Luther meninggal pada tahun 1546. Sebagai upaya untuk mengakhiri pertikaian seputar ajaran dan tetap mempersatukan para pengikut Luther, maka ditetapkanlah suatu ajaran baru dalam bentuk Formula Concordiae (Rumus Konkord/Kerukunan) pada tahun 1570 dan 
selesai disusun pada tahun $1580 .{ }^{15}$ Meskipun di dalam pendahuluan Buku Konkord Alkitab menjadi kaidah dan pedoman satu-satunya, tetapi segala hal yang diajarkan oleh Luther tetap menjadi pedoman yang kuat bagi gereja-gereja Lutheran. Berdasarkan tujuannya yang menjadikan pengakuan sebagai pedoman, Buku Konkord secara jelas menentang segala ajaran sesat yang bertentangan dengan pengakuan tersebut. ${ }^{16}$ Selain itu, penetapan Buku Konkord juga hendak menegaskan bahwa gereja-gereja Lutheran tetap memisahkan diri dari gereja-gereja aliran Reformed. Hal ini berkaitan dengan persoalan seputar Perjamuan Malam Kristus. Buku Konkord menyatakan, "percaya, mengajar dan mengaku bahwa di dalam Perjamuan Malam Kudus tubuh dan darah Kristus sungguh-sungguh dibagi-bagikan dan diterima."17 Secara tidak langsung, pengakuan ini juga hendak menentang orang-orang yang secara tersembunyi mengikuti ajaran Calvin.

Gereja-gereja Lutheran yang tergabung dalam Federasi Lutheran Dunia (The Lutheran World Federation/LWF) menjadikan Pengakuan Augsburg sebagai doktrin gereja. Selain pengakuan ini, Katekismus Besar dan Katekismus Kecil karya Luther juga menginspirasi pengakuan gereja-gereja Lutheran. Buku Konkord sebagai keterangan lanjutan setelah Pengakuan Augsburg tetap menjadi dokumen pengakuan gereja yang sah. ${ }^{18}$ Di Indonesia, sinode gereja HKBP yang menggabungkan diri dengan LWF memang mengacu kepada Pengakuan Augsburg, tetapi HKBP tetap merumuskan pengakuan imannya sendiri.

\section{Katekismus Heidelberg (KH)}

Tidak hanya Buku Konkord, Katekismus Heidelberg juga merupakan sebuah dokumen pengakuan yang lahir setelah Luther meninggal. Para pengikut Luther ada yang tetap mengikuti ajaran Luther, tetapi ada juga yang telah beralih kepada ajaran Calvin. Di saat mereka terus berjuang untuk melawan raja-raja Katolik yang hendak memusnahkan gerakan Reformasi, mereka pun melawan pengaruh Calvinis, sehingga mereka tetap menyuarakan untuk tetap mengikuti ajaran Luther saja. ${ }^{19}$ Katekismus Heidelberg karangan Zacharias Ursinus (1534-1583) dan Caspar Olevianus (15361587) diterbitkan pada Januari $1563 .{ }^{20}$ Ungkapan Luther dalam Katekismus Kecil: “Aku milik Kristus!" menjadi titik tolak Katekismus Heidelberg. Ungkapan ini 
merupakan penghiburan bagi orang Kristen yang memberi kekuatan untuk bertekun dalam iman. ${ }^{21}$

Katekismus Heidelberg dibagi menjadi tiga bagian besar. $^{22}$ Pertama, persekutuan dengan Kristus telah diungkapkan pada awal pengakuan ini sehingga Kristus bukanlah akhir, melainkan permulaan pengakuan ini. Kedua, pengakuan tentang ketritunggalan Allah hanya dapat dinyatakan melalui terang penyataan-Nya di dalam Kristus. Ketiga, pembahasan Kesepuluh Firman dibahas di bagian terakhir. Berawal dari Firman Allah dalam Roma 3:20, "tidak seorang pun yang dapat dibenarkan di hadapan Allah oleh karena melakukan hukum Taurat.”, Katekismus Heidelberg menekankan bahwa kita tidak dapat memperoleh kebenaran di hadapan Allah sekalipun kita menaati Kesepuluhan Firman-Nya. ${ }^{23}$

Pada masa Reformasi, setiap pengakuan tampaknya tidak luput dari pertentangan yang bersumber dari pihak-pihak yang tidak menyetujuinya. Hal ini pula yang terjadi pada Katekismus Heidelberg, sebab dokumen ini mendapat perlawanan dari aliran Luther dan Gereja Katolik Roma. Para pengikut Luther menentang dokumen ini karena dianggap menyimpang dari Pengakuan Iman Augsburg, ${ }^{24}$ sedangkan perlawanan dari Gereja Katolik Roma masih seputar teologi di dalam Perjamuan Kudus dengan tetap berpegang teguh pada Katekismus Romanus. ${ }^{25}$ Meskipun mendapat perlawanan, Katekismus Heidelberg tetap menyebar dan menjadi pedoman bagi gereja-gereja beraliran Reformed, tidak terkecuali di Indonesia. Katekismus ini dibawa oleh orang Belanda yang datang ke Indonesia dan dijadikan sebagai pedoman gereja yang telah diterjemahkan ke dalam beberapa bahasa sesudah zaman Vereenigde Oostindische Compagnie (VOC). Beberapa gereja di Indonesia yang mengacu kepada Katekismus Heidelberg antara lain: GKI, Gereja Toraja, Gereja Toraja Mamasa, BNKP, GBKP, Gereja-gereja Masehi Musyafir di Timor, dan Gereja Kristen Sumatera Bagian Selatan (GKSBS). ${ }^{26}$

\section{Pasal-pasal Ajaran Dordrecht (PAD)}

Perselisihan yang terjadi di kalangan gereja-gereja Reformasi mengenai doktrin predestinasi membuat gereja di Belanda pecah dan menghasilkan sebuah dokumen pengakuan yang baru, yaitu PAD. PAD secara resmi diumumkan di dalam sidang sinode yang bersifat terbuka pada 6 Mei $1619 .{ }^{27}$ Pengakuan ini terdiri dari 5 
pasal, yaitu: (1) pemilihan dan penolakan ilahi, (2) kematian Kristus dan penebusan manusia, (3 dan 4) kerusakan manusia: pertobatannya kepada Allah serta cara pertobatan, dan (5) ketekunan orang kudus. PAD sebenarnya diterbitkan untuk melawan ajaran Remonstran yang lahir dari pemikiran Jacobus Arminius (1560-1609). Ajarannya yang mengatakan bahwa pemilihan Allah berdasarkan kehendak bebas manusia merupakan bentuk perlawanan terhadap Confessio Belgica dan Katekismus Heidelberg. ${ }^{28}$ Meskipun demikian, sinode di Dordrecht tidak mendapatkan kesalahan dalam kedua dokumen tersebut yang menyimpang dari Firman Allah, sehingga diterbitkanlah PAD.

PAD ternyata juga berlaku di Indonesia. Ajaran ini masuk ke Indonesia melalui dua pintu. ${ }^{29}$ Pertama, PAD masuk melalui pekabaran Injil gereja-gereja di Indonesia yang menganggap bahwa pengakuan ini merupakan harta berharga yang harus diwariskan kepada gereja-gereja di Indonesia. Gereja yang dimaksud adalah Gereja Toraja, Gereja Toraja Mamasa, dan Gereja-gereja Reformasi di Indonesia (GGRI). Kedua, PAD masuk ke Indonesia melalui Pengakuan Iman Westminster, yang merupakan latar belakang Gereja Reformed Injili Indonesia. Meski ada gerejagereja di Indonesia yang masih mengacu kepada pengakuan ini, tetapi tetap perlu ada pengondisian sesuai dengan konteks Indonesia. Selanjutnya, kami akan menjabarkan bagaimana gereja-gereja di Indonesia menggumuli iman Kristen dengan konteks kehadirannya masing-masing.

\section{Gereja Toraja}

Gereja Toraja (GT) pertama kali mengadakan sidang sinode pada tahun 1947 dan menetapkan untuk menggunakan Tata Gereja Dordrecht dan menggunakan Tiga Naskah Keesaan Gereja-gereja Belanda sebagai Pengakuan Iman. Bukan tanpa alasan bahwa pengakuan dan tata Gereja Belanda menjadi hasil putusan dalam sidang itu. Para utusan Zending yang hadir dalam sidang tersebut rupanya masih mempunyai kedudukan yang lebih tinggi. Karena itu, hasil yang ditetapkan dalam sidang itu mengenai tata gereja dan pengakuan iman mendapat pengaruh dari Zending, atau dengan kata lain keputusan ini adalah kehendak Zending. ${ }^{30}$ Memang harus diakui bahwa sekalipun sudah menyatakan mandiri, tetapi ibarat seorang bayi yang baru 
belajar tentunya harus didampingi oleh sang ibu. Demikianlah juga bahwa GT masih harus didampingi oleh induknya.

Menurut Indu' Y. Panggalo, sebagaimana yang dikutip oleh Kobong, menyebutkan umumnya para utusan yang hadir dalam sidang sinode itu tidak mengerti dan bahkan tidak mengenal isi dari tata gereja dan pengakuan tersebut. Akibat dari hasil putusan itu adalah penahbisan pendeta hanya menjadi formalitas, karena para calon pendeta secara terpaksa mengakui dan menandatangani nota kesepakatan termasuk tata gereja dan PGT hanya untuk memenuhi syarat penahbisan, bukan karena mereka membutuhkannya. ${ }^{31}$ Tata gereja dan pengakuan yang dipaksakan oleh para zendeling nyatanya tidak berfungsi dalam GT.

Kemudian GT mulai menapaki kesadaran kritis, kesadaran agar mempunyai pengakuan sendiri yang sesuai konteks masyarakat Toraja. Pada tahun 1970, dalam Sidang Sinode di Sa'dan, Theodorus Kobong (1938-2008) dan A. J. Anggui merupakan dua tokoh yang merangsang peserta sidang untuk sadar bahwa GT perlu memiliki PGT sendiri yang sesuai dengan konteks masyarakat Toraja. Kobong mengatakan, materi PGT belum ada dalam peraturan gereja, yang ada hanyalah Naskah Keesaan yang perlu dianggap hanya sebagai referensi. Singkatnya, dokumen yang telah diakui GT sebelumnya tidak perlu dibuang sekalipun memang belum bisa dikatakan relevan dengan Toraja. Akan tetapi, justru itu dijadi-kan sebagai referensi untuk merumuskan pengakuan sendiri. Sementara Anggui, menandaskan bahwa GT perlu merumuskan pengakuan imannya sendiri berdasarkan Perjanjian Lama dan Perjanjian Baru. Tanpa pengakuan iman, maka GT akan ketinggalan dengan dunia yang begitu dinamis. ${ }^{32}$

Pada tahun 1972, Sinode di Palopo memutuskan untuk membentuk komisi yang bertugas merumuskan sebuah pengakuan yang singkat, sederhana, relevan, fungsional, dan kontekstual. Tahun berikutnya diadakan konsultasi perumusan pengakuan. Terdapat beberapa pendeta yang menyajikan makalah mengenai isu-isu penting yang berkaitan dengan pengakuan iman. Andarias Kabanga' (1951-2020) memberi catatan bahwa pengakuan harusnya berfungsi di tengah-tengah kehidupan sehari-hari. Sebab, ia merupakan respons manusia terhadap Allah. Ia juga merupakan respons manusia terhadap pernyataan Allah di dalam situasi konkret, di sini dan sekarang. ${ }^{33}$ A. Rumpa' menyuguhkan makalah mengenai perjumpaan GT dengan 
agama Islam. Yang perlu diperhatikan dalam pengakuan yang akan disusun adalah bagaimana iman Kristen dinyatakan dalam perjumpaan dengan sesama yang tidak seiman. F.K. Sarungallo menyoroti adat dan kepercayaan tradisional yang tentunya sesuatu yang tidak terpisahkan dari kehidupan masyarakat Toraja. Y. A. Sarira mengemukakan pentingnya menyadari konteks sosial, budaya, ekonomi dan politik yang disebutkan sangat tidak relevan dengan Tiga Naskah Keesaan. ${ }^{34}$

Dalam proses konsultasi beberapa hal umum yang disoroti. Pertama, pengakuan akan menggunakan kata "kita" dan bukan "kami", karena pengakuan tidak dipandang sebagai urusan internal, tetapi yang diutamakan adalah dimensi kebersamaan dan undangan bagi siapapun untuk bersama-sama mengaku. Pengakuan itu sebanyak mungkin menyatakan apa yang dipercayai, bukan menyebut-nyebut apa yang ditolak. ${ }^{35}$ Sidang Sinode XVI tahun 1981 di Makale telah menetapkan konsep pengakuan yang telah disusun dan yang juga telah mengalami beberapa revisi oleh Komisi Khusus Pengakuan GT. Pengakuan tersebut terdiri dari delapan bab dengan mukadimah "Yesus Kristus itulah Tuhan dan Juruselamat". ${ }^{36}$ Rumusan mukadimah tersebut yang merupakan inti rumusan pengakuan ini, dianggap sebagai salah satu bentuk sikap GT terhadap klasifikasi dalam masyarakat. Karena itu, tidak ada lagi to parengge' (kepala suku), to minaa (imam), dan kaunan (budak), semuanya satu di dalam Kristus. Hal ini secara eksplisit dijelaskan dalam Bab VI nomor 4 dan dalam Bab III nomor $2 .^{37}$

Mengenai persoalan adat, pengakuan yang dirumuskan setidaknya masih bersifat selektif terhadap adat yang bisa terima dan yang harus ditolak. Tentunya harus diuji terlebih dahulu adat-adat berdasaran kehendak Allah (Bab VII, 8). Dalam perjumpaan dengan tradisi dewa-dewa Toraja, pengakuan ini dengan jelas menyatakan keesaan Allah tanpa menyangkal ketritunggalan Allah dalam tiga pribadi (Allah, Anak dan Roh Kudus). ${ }^{38}$

Kemudian keselamatan tidak lagi ditentukan oleh hewan kurban, amal perbuatan baik, atau persembahan, tetapi oleh pembenaran Allah di dalam Yesus Kristus. Bagian ini merupakan salah satu warisan dari tradisi Calvinis yang masih dipegang oleh GT. Mengenai dosa GT dengan jelas menyatakan bahwa persekutuan dengan arwah-arwah adalah hal sia-sia dan merupakan dosa terhadap Allah. ${ }^{39}$ 
Masih mengenai arwah, salah satu PGT menyatakan bahwa manusia mati seutuhnya. Hal ini dipakai untuk menghadapi adat yang selama ini dipercayai bahwa manusia yang telah meninggal setelah berbagai pelaksanaan upacara adat arwah orang Toraja akan membali puang (divinisasi). Akibatnya, ada kecenderungan dari orang yang masih hidup untuk berinteraksi dengan mereka yang telah meninggal melalui patung-patung nenek moyang dan lain-lain. ${ }^{40}$

Kabanga' mencoba mendialogkan budaya Toraja dengan Iman Kristen. Menurutnya, tidak ada yang ilahi dalam diri manusia. Manusia mati seutuhnya berarti bahwa manusia dalam segala aspek pada dirinya. Kematian itu sendiri menjadi berarti karena anugerah Allah. Karena itu, ketika pada akhir zaman, yang dibangkitkan bukan hanya tubuh saja melainkan satu manusia utuh. Dengan kata lain, pengakuan yang menyatakan bahwa manusia mati seutuhnya ingin mengatakan bahwa manusia dibangkitkan seutuhnya. ${ }^{41}$ Yang perlu diluruskan oleh GT sendiri adalah anggapan mengenai setelah kematian tidak terjadi apa-apa lagi. Kabanga' memaparkan bahwa justru di dalam iman kepada Kristus yang telah menyelamatkan manusia melalui kematian dan kebangkitan-Nya sehingga kematian manusia mempunyai makna. Dalam PGT dijelaskan dalam Bab VIII nomor 6:

Hidup di dalam hubungan dengan Allah adalah hidup yang kekal, yang tidak dapat ditiadakan oleh kuasa apapun. Allah dalam kuasa dan kasih setia-Nya melanjutkan hubungan itu, sehingga setiap orang percaya sesudah mati, berada bersama-sama dengan Kristus. Setiap orang yang tidak percaya berada di luar persekutuan dengan Kristus. ${ }^{42}$

Karena itu, anggapan adanya diskontinuitas setelah kematian dipatahkan dan semakin meyakinkan orang Toraja bahwa kematian yang dialami bukanlah akhir segalnya, tetapi justru hidup bersama dalam Kristus. ${ }^{43}$

Selain itu, Islam menjadi sorotan penting dalam PGT karena ada banyak orang Islam hidup di Toraja meskipun dalam persentase yang kecil dan juga telah mengambil banyak peranan di berbagai aspek kehidupan Toraja. Selain itu, banyak orang Toraja yang merantau ke tempat yang mayoritas penduduknya beragama Islam. Sementara itu, perkembangan modern menjadi konteks yang diperhatikan PGT juga secara implisit. Perkembangan itu adalah ilmu pengetahuan, dan teknologi serta semakin banyaknya orang Toraja berdiaspora di berbagai tempat. GT mau tidak mau akan masuk ke dalam dunia modern. Karena itu, Islam dan perkembangan modern 
telah menjadi konteks yang dihadapi GT dan membuatnya harus menentukan sikap terhadap konteks-konteks yang dihadapi. ${ }^{44}$ Harus diakui bahwa PGT tidak secara eksplisit menyatakan sikap terhadap dua konteks itu, tetapi yang jelas GT tidak menyatakan sikap eksklusif dan tertutup.

\section{Gereja Kristen Indonesia dan Konfesi 2014}

Proses merumuskan ajaran GKI termasuk pemahaman dan pengakuan iman tidaklah mudah, meskipun GKI terus berusaha menjadi gereja yang bersatu. Hal ini disebabkan oleh latar belakang terbentuknya GKI pun berawal dari perbedaan antara GKI Jawa Barat, Jawa Tengah, dan Jawa Timur. Sebelum menjadi satu dalam Sinode GKI, ketiga gereja ini telah menetapkan rumusan pemahaman dan pengakuan imannya sendiri.

Nederlandsche Zendingsvereeniging (NZV) mulai bekerja di Jawa Barat pada tahun 1863. Pekabaran Injil yang dilakukan oleh NZV di kalangan orang Tionghoa di Jawa Barat tahun 1938 berhasil mendirikan Tiong Hoa Kie Tok Kauw Hwee - Khoe Hwee Djawa Barat (THKTKH-KHDB, Gereja Kristen Tionghoa Klasis Djawa Barat) yang pada tahun 1954 namanya diubah menjadi GKI Jabar. Dasar pengakuan iman yang ditetapkan oleh GKI Jabar sebenarnya sama dengan pengakuan iman GPI. Hal ini tertuang dalam Peraturan Gereja Pasal II tahun 1961 yang menyatakan, "Iman dan hidup Gereja Kristen Indonesia Jawa Barat berasaskan Firman Allah, yakni Perjanjian Lama dan Perjanjian Baru, dalam persekutuan yang hidup dan kudus dengan pengakuan iman Gereja segala abad sesuai dengan ajaran Reformasi." ${ }^{45}$ Rumusan umum ini diganti dengan rumusan yang lebih konkret di dalam Tata Gereja 1978 pasal $2^{46}$ :

(1) Dasar GKI Jabar adalah Tuhan Yesus Kristus - Allah dan manusia - yang telah hidup, mati, dan bangkit, untuk keselamatan seluruh umat manusia dan dunia, seperti yang disaksikan oleh Alkitab Perjanjian Lama dan Perjanjian Baru.

(2) Dalam persekutuannya dengan Gereja segala abad dan tempat, GKI Jabar menghayati imannya sesuai dengan azas-azas Pengakuan Iman Rasuli, Pengakuan Iman Nicea-Konstantinopel, dan Pengakuan Iman Athanasius; serta dalam ajarannya berpegang pada azas-azas Reformasi.

Gereja Kristen Tionghoa Jawa Tengah terbentuk pada tahun 1945 dan berganti nama menjadi Gereja Kristen Indonesia Jawa Tengah (GKI Jateng). GKI Jateng mengalaskan pengakuannya pada Kitab Suci dan 12 Pasal Pengakuan Iman Rasuli 
sesuai dengan penjelasan Katekismus Heidelberg. ${ }^{47}$ Hal ini tercantum dalam Tata Gereja yang ditetapkan di Magelang tahun 1994, "Sebagai gereja reformasi, GKI Jateng menerima pengajaran reformasi yang tercantum dalam Katekismus Heidelberg." (THKTKH-KHDT, Gereja Kristen Tionghoa Klasis Djawa Timur) mempunyai warna tersendiri dalam pemahaman dan pengakuan imannya. Ajarannya tidak murni beraliran Calvinis, sebab ada unsur Injili di dalamnya. Pengakuan iman GKI Jatim disarikan dari pengakuan iman yang diakui oleh teologi Reformasi, seperti: Symbolum Apostolicum, Pengakuan Iman Nicea-Konstatinopel, Pengakuan Iman Westminster, Confessio Belgica, dan $\mathrm{KH} .{ }^{49}$ Groen mencatat bahwa pengakuan yang dibuat oleh GKI Jatim bertujuan untuk mengakomodasi panggilan pemberitaan Injil seperti yang dinyatakan berikut ini:

Bahwa Gereja ada di dalam dunia untuk memberitakan Injil Yesus Kristus dan mengungkapkan ketuhanan Kristus lewat perbuatan-perbuatan nyata. Gereja menjalankan misi Yesus Kristus, yaitu menegakkan pemerintahan Kerajaan Allah atas dunia ini, baik mela-lui usaha-usaha penginjilan di dunia ini maupun usaha-usaha menyatakan dan mewujudkan kebenaran dan keadilan di dalam kasih untuk memperbaharui dunia." 50

Pada tahun 1988, tiga gereja yang dulu adalah Gereja Tionghoa di Jawa, yaitu:

GKI Jawa Tengah, GKI Jawa Barat, dan GKI Jawa Timur menggabungkan diri menjadi Gereja Kristen Indonesia (GKI). Sebagai upaya menjadi gereja yang bersatu, GKI menetapkan tata gerejanya pada tahun 2002 dan di dalamnya pun terdapat penjelasan tentang pengakuan iman yang dipahami oleh GKI secara keseluruhan. Di dalam tata gerejanya, pasal 3, GKI menerangkan pengakuan imannya sebagai berikut: ${ }^{51}$

(1) GKI mengaku imannya bahwa Yesus Kristus adalah

(a) Tuhan dan Juruselamat dunia, Sumber kebenaran dan hidup.

(b) Kepala Gereja, yang mendirikan gereja dan yang memanggil gereja untuk hidup dalam iman dan misinya.

(2) GKI mengakui imannya bahwa Alkitab Perjanjian Lama dan Perjanjian Baru adalah Firman Allah, yang menjadi dasar dan norma satu-satunya bagi kehidupan gereja.

(3) GKI dalam persekutuan dengan Gereja Tuhan Yesus Kristus di segala abad dan tempat, menerima Pengakuan Iman Rasuli, Pengakuan Iman NiceaKonstantinopel, dan Pengakuan Iman Athanasius.

(4) GKI, dalam ikatan dengan tradisi Reformasi, menerima Katekismus Heidelberg. 
(5) GKI, dalam persekutuan dengan gereja-gereja di Indonesia, menerima Pemahaman Bersama Iman Kristen dari Persekutuan Gereja-gereja di Indonesia.

Persidangan Majelis Sinode GKI ke-XVIII pada tahun 2014 kemudian menyahkan konfesi GKI. Konfesi baru ini bertemakan "Berperan serta ke dalam Persekutuan Kasih dan Karya Keselamatan Allah Bapa, Anak, dan Roh Kudus" yang didasarkan pada pemahaman Trinitas yang dianut oleh GKI sendiri. ${ }^{52}$ Konfesi ini mendasarkan seluruh percakapan dan pengakuan imannya dalam teologi Trinitas yang meyakini Allah Bapa, Yesus Kristus, dan Roh Kudus adalah satu hakikat di dalam tiga Pribadi, yang berbeda satu sama lain, dan bersekutu di dalam relasi kasih. ${ }^{53}$

\section{Huria Kristen Batak Protestan (HKBP)}

Pada awalnya Huria Kristen Batak Protestan (HKBP) tidak terikat pada satu pengakuan iman dan denominasi tertentu. Selain itu, Groen menjelaskan bahwa ternyata belum ada kebutuhan dari HKBP sendiri untuk membedakan diri dari aliran kekristenan lain. ${ }^{54}$ Belum ada interaksi yang intens antara HKBP dengan dunia luar, sehingga watak gereja Protestan dengan ciri pietisme Lutheran hingga pasca tahun 1930-an belum mendapat rintangan, terutama dari dunia luar. Mengenai persoalan dengan Islam dan adat Batak, HKBP mempunyai pernyataan singkat mengenai iman Kristen. Beberapa tahun berikutnyalah HKBP berhadapan dengan perubahan yang begitu drastis seperti semakin banyaknya aliran kekristenan, budaya, dan politik yang kemudian menuntut kesiapan dan sikap HKBP sendiri. ${ }^{55}$

Terhitung sejak awal abad ke-20, Sumatera didatangi banyak pekabar Injil dari berbagai denominasi, seperti Metodist, Baptis, Adventis, dan Pantekosta. Di antara aliran-aliran tersebut, Pentakostalah yang paling berkembang pesat. Sementara pada awal tahun 1930-an Gereja Katolik mulai menapakkan kaki di tanah Batak. Setelah menghasilkan buah dengan masuknya orang-orang Batak ke Gereja Katolik, mereka menjadi musuh HKBP.

Selain itu, dalam intern HKBP sendiri muncul ketidakpuasan akan pemimpin asing dalam HKBP. Mereka memisahkan diri dan membentuk Huria 123 yang dikemudian hari dikenal sebagai Mission Batak. Kemudian muncul lagi gerakan menolak pimpinan orang Barat dalam HKBP, mereka dikenal sebagai Hatopan Kristen Batak yang setelah pasca kemerdekaan dikenal sebagai Huria Kristen Indonesia. $^{56}$ 
Dalam relasinya dengan dunia Internasional, HKBP pada tahun 1948 mengajukan diri menjadi anggota Lutheran World Federation (LWF), tetapi belum bisa diterima karena konstitusi HKBP tidak mencantumkan dasar ajarannya. Dengan kata lain, HKBP harus satu ajaran dengan Gereja Lutheran. Dalam sebuah pertemuan gereja-gereja Lutheran di Rajahmundry, India, diberi kesempatan kepada HKBP untuk mempertimbangkan dirinya menyetujui ajaran Lutheran. ${ }^{57}$

Untuk itu sidang sinode HKBP diadakan untuk membahas pengakuan iman sehubungan dengan keinginan untuk menjadi anggota LWF. Namun, di satu sisi, Rheinische Missionsgesellschaft (RMG) sebagai induk pekabaran Injil di tanah Batak kurang setuju bila HKBP menjadi anggota LWF dengan pertimbangan bahwa HKBP mengharapkan bantuan dari organisasi bersangkutan. Gustav Weth sebagai tokoh RMG mengirimkan surat kepada ephorus untuk mempertimbangkan agar merumuskan pengakuan sendiri. Setidaknya, HKBP mengadakan riset atau pengkajian yang mendalam terhadap pengakuan Augsburg dan diterjemahkan ke dalam bahasa Batak apabila HKBP sendiri tetap ingin mendapatkan keanggotaan itu. ${ }^{58}$

Untuk menanggapi hasil keputusan di Rajahmundry dan saran dari Gustav Weth, HKBP mengadakan pertemuan dalam tiga rapat. Rapat pertama pada Maret 1950, dinyatakan akan memperkenalkan kepada LWF mengenai kehidupan bergereja HKBP telah menjadi Lutheran karena telah menggunakan Ketekismus Kecil Luther untuk mendidik anak-anak dan khotbah-khotbah sudah berdasarkan Pengakuan Augsburg.

Rapat kedua pada Juni, Pengakuan Augsburg telah diterjemahkan ke dalam bahasa Batak untuk dibahas dalam rapat ini. Rapat ini ternyata menjadi sebuah batu loncatan untuk membicarakan perumusan pengakuan sendiri terlepas dari urusan LWF. Beberapa peserta menyatakan bahwa Pengakuan Augsburg sama sekali tidak akan bermanfaat bagi HKBP, serta beberapa istilah mereka tidak pahami, seperti kaum Donatis, dan kaum Anabaptis. Sekalipun demikian, tugas yang ditetapkan Justin Sihombing selaku ephorus adalah menyusun pengakuan sebagai dasar untuk menerangkan pendirian HKBP kepada LWF. Rapat ketiga pada bulan November menetapkan sejumlah pendeta yang bertugas untuk merumuskan pengakuan sendiri dan menolak Pengakuan Augsburg sebagai pengakuan HKBP. ${ }^{59}$ 
Berdasarkan keputusan itu, Justin Sihombing mengambil inisiatif sendiri untuk menyusun pengakuan Iman tanpa bantuan teolog lain. Pengakuan yang disusunnya tetap berangkat dari Pengakuan Augsburg dengan mempertimbangkan konteks yang dihadapi HKBP. Namun pengakuan ini kurang disambut dengan baik oleh banyak orang. Panitia yang telah dibentuk merasa bahwa tidak ada bahan pembanding untuk rumusan Sihombing ini dan beberapa orang kurang sependapat mengenai isinya. Bahwa pengakuan mengenai akhir zaman semestinya pembahasannya lebih luas dan juga harus lebih visioner. Akan tetapi, pengakuan hasil perumusan Sihombing tidak dibuang begitu saja, melainkan akan dirujuk kepada Panitia penyusun Konfesi. ${ }^{60}$

Dalam proses perumusan oleh panitia, pengakuan rumusan Sihombing tidak disertakan karena telah ditolak oleh konferensi pendeta. Namun, tidak ada usulan rumusan yang masuk ke panitia selain dari rumusan Sihombing. Akibatnya tidak ada pilihan lain untuk tetap memasukkan rumusan Sihombing; hanya saja, panitia hanya mengambil pendahuluannya saja dan seluruh strukturnya diganti menjadi struktur baru. Langkah selanjutnya melibatkan beberapa utusan dari luar negeri seperti J. Bos, L.W. Korvinus dari Belanda, A. K. Klaus dari Amerika Serikat, serta dua orang utusan LWF.

Utusan gereja-gereja luar negeri tidak terlalu banyak memberikan kontribusi dalam perumusan ini. Hal ini juga menghindari anggapan bahwa pengakuan HKBP banyak mendapat pengaruh dari luar. Akan tetapi, setidaknya utasan-utusan itu memberi sumbangan berupa penekanan atas kerasulan, dan kesalahpahaman persoalan Tritunggal oleh saudara-saudara Muslim. Selain itu, demi menjalin relasi dengan gereja-gereja Reformed di Indonesia, mengenai Perjamuan Kudus panitia meminta persetujuan dari Korvinus, seorang pendeta sebagai wakil dari Belanda dan ternyata pemahaman Perjamuan Kudus antara gereja Lutheran dan Reformed merupakan satu mata rantai sehingga tidak menjadi persoalan. ${ }^{61}$ Setelah itu pengakuan yang telah disepakati sewaktu-waktu dapat disesuaikan dan ditambahkan, bila ternyata di kemudian hari terdapat kekurangan dan kesalahan di dalamnya. Kemudian hasil rumusan ini bersama dengan Katekismus Kecil Luther ${ }^{62}$ dan Aturan HKBP akan dikirim ke LWF untuk proses keanggotaan. ${ }^{63}$

Seperti yang telah dijelaskan sebelumnya, LWF memberi kesempatan HKBP untuk memikirkan keinginan mereka untuk menjadi anggota dengan tentunya 
memperhatikan syarat mutlak, yaitu mengakui Pengakuan Augsburg sebagai dasar. Namun seiring berjalannya waktu LWF mulai menetapkan bahwa pengakuan Augsburg bukanlah syarat mutlak dan memang tidak bisa dijadikan sebagai hukum iman. ${ }^{64}$ Sesungguhnya juga HKBP telah mengambil sebuah langkah besar, karena tidak tunduk pada satu peraturan LWF dan memilih jalan lain dengan merumuskan pengakuan sendiri. Pada akhirnya HKBP sendiri diterima sebagai anggota LWF, karena pengakuan imannya telah mengandung pengakuan-pengakuan Lutheran. Hal ini patut diperhatikan gereja-gereja di Indonesia, bahwa tidak patut kita menjunjung tinggi tradisi gereja tetapi mengabaikan konteks kita yang sesungguhnya. ${ }^{65}$

Pada Sinode Godang HKBP pada tahun 1996, Konfesi HKBP mengalami perubahan. Salah satunya adalah perampingan daftar ajaran sesat yang ditolak menjadi lebih singkat, yaitu menolak ajaran yang tidak sesuai firman Allah. Selain itu tidak banyak perubahan yang signifikan pada perumusan kedua ini. ${ }^{66}$ Namun yang perlu dicatat pada pengakuan kedua ini adalah bahwa tujuan utamanya membina warga jemaat HKBP. Isi pengakuan sendiri sudah menggunakan kata "kita" yang berarti bahwa pengakuan ini sudah diarahkan untuk dalam kalangan HKBP sendiri. ${ }^{67}$

\section{Gereja-gereja Kristen Jawa}

Pada tahun 1931, Gereja Gereformeerd Jawa Tengah berubah nama menjadi Gereja-gereja Kristen Jawa (GKJ). Gereja ini sangat berpedoman kepada KH sehingga mereka menerjemahkan $\mathrm{KH}$ ke dalam bahasa Jawa agar mudah dimengerti. Dua dokumen pengakuan lainnya (Confessio Belgica dan PAD) juga diterjemahkan ke dalam bahasa Jawa oleh pendeta Wilhelm. Oleh karena mereka sangat berpedoman kepada KH, maka GKJ dalam Tata Gerejanya, pada tahun 1932, mewajibkan para pelayan untuk menandatangani nota kesepaktakan terhadap KH. Hal ini juga tertuang dalam konsep revisi Peraturan Gereja GKJ (1975) yang menyatakan bahwa "Gerejagereja Kristen Jawa menerima Pelajaran Agama Kristen (Katekismus Heidelberg) sebagai keterangan pengakuan iman gereja."68 Penandatanganan tersebut pada akhirnya membentengi cikal bakal GKJ ini dari sinkretisme dan mistisisme Jawa. ${ }^{69}$

Pada tahun 1996, sinode GKJ memutuskan bahwa Pokok-pokok Ajaran Gereja-gereja Kristen Jawa menggantikan Katekismus Heidelberg yang telah berpuluh-puluh tahun diberlakukan dalam GKJ. Proses perumusannya memang sudah 
dilakukan sejak tahun 1984 saat GKJ menyusun ajarannya. Hal ini dilakukan oleh GKJ sebagai upaya untuk menjadi gereja yang mandiri, sehingga GKJ tidak hanya menerima begitu saja pengakuan tersebut. GKJ mempertanyakan warisan pengakuan itu berdasarkan kebenaran Alkitab yang disesuaikan dengan konteks GKJ. Inti dari pengakuan yang dibuat oleh GKJ tetap mengacu kepada Katekismus Heidelberg bahwa keselamatan hanya karena anugerah Allah yang diterima dengan beriman. Dengan demikian, GKJ tetap berpegang pada ajaran Reformasi, yaitu: Sola Scriptura, Sola Fide, dan Sola Gratia. ${ }^{70}$

Pengakuan GKJ ini berbentuk katekismus dan terdiri dari 310 tanya jawab, yang dibagi ke dalam lima bab, yaitu: (1) Ajaran Gereja, (2) Alkitab, (3) Penyelamatan Allah dan Gereja, (4) Tata Kehidupan Gereja, dan (5) Orang Percaya dan Kehidupan Manusia di Dunia. ${ }^{71}$ Keseluruhan Pokok-pokok Ajaran GKJ dibagi ke dalam 28 minggu. Dokumen pengajaran GKJ yang berbentuk katekismus ini (tanyajawab) sebenarnya dapat membantu umat untuk lebih memahami segala ajaran yang diakui oleh GKJ, sehingga umat dapat menentang ajaran sesat yang tidak sesuai dengan pemahaman GKJ. Di dalam pengakuan tersebut, GKJ memberikan tempat yang cukup untuk menjelas-kan peranan Pengakuan Iman Rasuli dalam menyusun pengakuannya sendiri. Hal ini tertuang dalam Bab 5 pada minggu ke-26 tentang Pengakuan Iman Rasuli. ${ }^{72}$

Dalam Pokok-pokok Ajaran GKJ, sinode GKJ secara jelas menyatakan bahwa upaya menyusun pengakuan imannya sendiri tidak disertai dengan niat untuk melepaskan Pengakuan Iman Rasuli yang selama ini menjadi pegangan utama. ${ }^{73}$ Dalam edisi tahun 2005, Pengakuan Iman Rasuli dipahami dalam bingkai PPA GKJ. ${ }^{74}$ Hal ini membuat GKJ mempunyai dua sikap dalam memandang Pengakuan Iman Rasuli. Kedua sikap itu adalah:

(1) Pengakuan Iman Rasuli adalah pengakuan iman yang dilahirkan oleh Gereja awal, yang berisikan inti pengajaran rasul-rasul mengenai Allah dengan penyelamatan yang dikerjakan-Nya ke atas manusia.

(2) Melalui Pengakuan Iman Rasuli yang dipegangnya itu, GKJ menjalani kehidupannya dengan menghayati dirinya berada di dalam satu garis sejarah penyelamatan Allah di dalam segala zaman dan di segala tempat. ${ }^{75}$

Di dua edisi tersebut (1997 dan 2005), sinode GKJ kembali menekankan alasan mereka menyusun PPA GKJ meskipun masih tetap berpegang teguh pada Pengakuan Iman Rasuli. Alasannya adalah GKJ merasa perlu mengembangkan dan memperkaya, 
serta menerapkan Pengakuan Iman Rasuli di dalam dunianya pada zamannya dengan kondisi yang khas. ${ }^{76}$ Dengan kata lain, melalui PPA GKJ, Pengakuan Iman Rasuli dapat dipahami dengan baik oleh umat sesuai dengan konteks GKJ. Akan tetapi, GKJ mempunyai batasan dalam mengembangkan, memperkaya, dan menerapkan Pengakuan Iman Rasuli di dalam PPA GKJ yang disusunnya. Batasan itu adalah Alkitab sehingga PPA GKJ tidak boleh bertentangan dengan Alkitab.

GKJ tampaknya menjadi salah satu gereja Protestan di Indonesia yang tidak hanya telah menyusun pengakuan imannya sendiri, tetapi isi yang terkandung di dalamnya telah sesuai dengan konteks kehidupan di dunia. Hal ini sudah terlihat dalam pandangan GKJ tentang sikap manusia terhadap alam, sikap gereja terhadap kehidupan sosial-politik negara, dan pandangan GKJ tentang agama-agama lainnya. Semua itu secara jelas dituangkan dalam PPA sehingga umat dapat memahami apa yang dipikirkan oleh GKJ tentang persoalan-persoalan itu. Simon Rachmadi, dalam disertasinya, juga menegaskan bahwa PPA GKJ merupakan wujud GKJ mempertahankan suara kenabiannya pada masa rezim Orde Baru. Penekanan lain dari Rachmadi adalah bahwa dokumen ini merupakan sebentuk pergulatan GKJ dalam mempertemukan teologi Reformasi dan spiritualitas kejawaan. ${ }^{77}$

\section{Perbandingan dengan Pengakuan Bersama Iman Kristen}

Pembahasan mengenai pengakuan iman bersama merupakan tonggak penting lahirnya gerakan ekumenis di Indonesia. Pada awalnya dalam tubuh badan-badan Zending tumbuh kesadaran untuk tidak menekankan asas masing-masing, namun justru menekankan tujuan bersama yang menjadi kebutuhan di Indonesia. Walaupun demikian belum ada usaha untuk mewujudkan gagasan ini karena belum ada organisasi yang mewadahinya. Yang ada hanya Zendingsconsulaat (wakil zending) yang setidaknya mewadahi badan-badan Zending Belanda untuk bekerja sama. ${ }^{78}$

Todung Sutan Gunung Mulia (1896-1966), ${ }^{79}$ seorang mahasiswa pengurus Christen Studenten Vereniging op Java (CSV) mewakili Indonesia dalam sebuah pertemuan International Missionary Council (IMC) tahun 1928 di Yerusalem. Gunung Mulia mendukung pendirian Dewan Gereja-Gereja Indonesia (DGI), serta juga mendukung lahirnya Hogere Theologische School (HTS, kini STFT Jakarta) pada tahun 1934 untuk menjadi sekolah pendidikan pendeta di seluruh Indonesia. Upaya 
pendirian DGI ini terus dikobarkan pasca Perang Dunia II yang juga dipicu oleh adanya rasa nasionalisme sehingga badan-badan Zending tidak lagi terlibat dalam usaha itu. Hingga pada tahun 1950 barulah DGI dapat terealisasi dan berdiri. ${ }^{80}$

Bahasan mengenai pengakuan ini merupakan bahasan yang terus berkelanjutan dalam perkembangan PGI terutama sejak tahun 1950. Sidang Raya DGI VI 1967 di Makassar yang bertajuk Pembentukan Gereja Kristen Yang Esa di Indonesia menghasilkan gagasan mengenai Pemahaman Iman Bersama (PIB). Pengakuan itu meliputi Allah Yang Esa, Yesus Kristus, Roh Kudus, Gereja, Firman Allah, Sakramen, Jabatan, Tertib Gereja, Dosa dan Keampunan, Pengharapan Kristen, dan Pemerintah. ${ }^{81}$ Dua Sidang Raya yang digulirkan pada tahun 1971 di Siantar dan pada tahun 1980 di Tomohon sepakat melakukan konsultasi secara nasional dan regional serta mendorong gereja-gereja anggota DGI untuk membentuk gereja yang esa di Indonesia. Sidang Raya berikutnya di Ambon menghasilkan dokumen Pokok-pokok Tugas Panggilan Bersama (PTPB) yang menyatakan bahwa gereja-gereja harus bersama-sama menjawab tantangan-tantangan yang nyata, urgen, dan aktual. Dokumen kedua yang dihasilkan dari sidang itu adalah Pengakuan Bersama Iman Kristen (PBIK). Pengakuan ini dihasilkan agar gereja-gereja dapat bekerja sama dalam program PTPB. PBIK ini dalam dokumen DGI dijadikan nomor satu dengan sebuah kesadaran bahwa para anggota memiliki latar belakang tradisi teologis yang berbeda. $^{82}$

Pengakuan yang telah ditambahkan sejak dirumuskan pada tahun 1967 ini mendapat sambutan hangat dari anggota-anggota PGI. Anggota-anggota tidak berusaha untuk mencari jalan lain atau menolak, tetapi turut berpartisipasi dalam penyusunan PBIK. Pengakuan ini juga lebih bersifat alkitabiah dan tidak sebatas mengutip dari Alkitab semata. Beberapa hal yang terdapat dalam pengakuan ini adalah persoalan mengenai kontekstual, dosa dan pelunasan, pendamaian, perdamaian, Missio Dei, Kerajaan Allah, dan agama-agama lain. ${ }^{83}$

\section{Mengaku Allah dan Merupa dalam Konteks}

Gereja dan orang Kristen di Indonesia saat ini harus mulai berpikir kritis tentang pengakuan imannya. Kita memang tidak dapat menghilangkan akar tradisi pengakuan iman sebuah gereja. Sebagai gereja yang lahir dari pekabaran Injil negara- 
negara Eropa, kita tidak dapat memungkiri bahwa pengakuan iman sebagian besar gereja di Indonesia masih merupakan warisan dari pengakuan iman para pekabar Injil di masa lalu. Akan tetapi, banyak pula gereja di Indonesia yang tidak mengetahui asalusul pengakuan iman yang diucapkannya di setiap ibadah Minggu. Kita sering kali berada dalam posisi hanya menerima saja pengakuan iman tersebut, tanpa pernah berpikir tentang latar belakang gereja kita menjadikannya sebagai pengakuan iman umat dalam ibadah.

Selain itu, kita pun jarang sekali berpikir kritis tentang pengakuan iman gereja kita; apakah pengakuan iman ini sudah sesuai dengan konteks pergumulan umat Kristen di masa kini, atau ini hanya merupakan sebuah warisan yang harus diajarkan turun-temurun kepada generasi berikutnya? Kita memandang bahwa pengakuan iman merupakan sesuatu yang sudah mutlak, sehingga tidak boleh mengalami pembaharuan sesuai dengan konteks umat Kristen masa kini. Apabila gereja-gereja dan orang Kristen di Indonesia masa kini memahami bahwa pengakuan iman merupakan jawaban umat terhadap Firman Allah yang diberitakan, maka pengakuan iman yang kita ucapkan dan yakini seharusnya mampu mencerminkan konteks umat dan pergumulannya di masa kini. Sebagaimana yang dikatakan Christiaan de Jonge, dalam bukunya Apa itu Calvinisme?, gereja-gereja Protestan di Indonesia seharusnya sudah mempunyai kesadaran bahwa mereka dipanggil untuk mengaku Kristus dalam konteks Indonesia dengan rumusan-rumusan yang tidak diwarisi dari gereja-gereja lain, tetapi diciptakan sendiri. ${ }^{84}$

Leo J. Koffeman, seorang pengajar di Protestantse Theologische Universiteit Amsterdam, menandaskan bahwa pengakuan iman merupakan penanda identitas gereja. Pengakuan iman merupakan pergulatan dan pergumulan serius nan panjang dengan konteks kehadirannya. ${ }^{85}$ Pergulatan panjang yang tertuang dalam konfesi tersebut memperlihatkan adanya kontinuitas sebuah gereja dengan tradisi dan pergulatan gereja-gereja di sepanjang abad dan zaman. ${ }^{86}$

Gereja Toraja, GKI, HKBP, dan GKJ telah menegaskan posisi di antara dua tegangan penting, yakni antara tradisi dan kesadaran konteks, baik dalam konteks lokal (budaya setempat, beban sejarah) maupun dalam konteks yang lebih luas (nasionalisme, relasi dengan gereja-gereja lain, ekumenisme dsb). Rumusan Pengakuan Iman mereka menjadi hasil negosiasi antara dua tersebut, tradisi dan 
konteks. Dengan demikian, kehadiran gereja adalah untuk mengaku tentang yang ilahi serta merupa dalam konteks kehadiran sesuai pengakuannya. Gerakan Ekemunisme di Indonesia juga kemudian menjadi wujud kesadaran Indonesia sebagai rumah bersama. Dengan demikian, PBIK juga adalah wajah pengakuan akan Allah dalam kesadaran konteks Indonesia.

\section{KESIMPULAN}

Kita telah melihat bagaimana sejarah pergulatan gereja-gereja di Indonesia, dalam hal ini Gereja Toraja, GKI, HKBP, dan GKJ dalam merumuskan pengakuannya dalam konteks di mana ia hadir. Proses "mengakar" sebuah gereja pada tradisinya bukan sesuatu yang secara mutlak dipertahankan, tanpa menyadari situasi kehadiran gereja. Secara khusus, gereja-gereja tersebut di atas bergulat dengan budaya lokal, perkembangan zaman, relasi dengan agama lain, dan kesadaran ekumenis. Pergulatan itu diwujudkan dalam pengakuan iman.

\section{Endnotes:}

\footnotetext{
${ }^{1}$ B F Drewes and Julianus Mojau, Apa Itu Teologi?: Pengantar Ke Dalam Ilmu Teologi (BPK Gunung Mulia, 2003).

2 Radius Aditiya Jonar, "Teologis Atau Politis?: Pencarian Makna Pergulatan Historis Dalam Pengakuan Iman Nicea-Konstantinopel,” Jurnal Theologia in Loco 2, no. 1 (2020): 48-71.

3 Ebenhaizer Nuban Timo, "Gereja Merumuskan Jawaban: Sebuah Bentuk Pengakuan Iman Kontemporer Di NTT,” BERBAGI: Jurnal Asosiasi Perguruan Tinggi Katolik 3, no. 2 (2014): $217-48$.

${ }^{4}$ George W. Forell, The Augsburg Confession: A Contemporary Commentary (Minneapolis, MN: Augsburg Publishing House, 1968).

5 Theodore G. Tappert and Mangisi S.E. Simorangkir, eds., Buku Konkord: Konfesi Gereja Lutheran (Jakarta: BPK-Gunung Mulia, 2004).

${ }^{6}$ G. I. Williamson, The Heidelberg Catechism (P\&R Publishing, 1993).

${ }^{7}$ Thomas van den End, ed., Enam Belas Dokumen Dasar Calvinisme (Jakarta: BPK Gunung Mulia, 2004).

${ }^{8}$ Jacob P. D. Groen, Terpanggil Untuk Mengakui Iman: Pembimbing Ke Dalam DokumenDokumen Pengakuan Gereja, ed. Widyowati Purwanto and Chrisostomus Sihotang (Jakarta: BPK Gunung Mulia, 2012).

${ }^{9}$ Groen.

${ }^{10}$ Groen.

${ }^{11}$ Groen.

12 Hartmut Lehman, "Lutheranism in the Seventeenth Century," in The Cambridge History of Christianity: Vol. 6 Reform and Expansion 1500-1660, ed. R. Po-chia Hsia (Cambridge: Cambridge University Press, 2008), 57; Groen, Terpanggil Untuk Mengakui Iman.

${ }^{13}$ Groen, Terpanggil Untuk Mengakui Iman.

${ }^{14}$ Groen.

${ }^{15}$ Groen.
} 
${ }^{16}$ Christiaan de Jonge, Gereja Mencari Jawab: Kapita Selekta Sejarah Gereja (Jakarta: BPK Gunung Mulia, 2003), 89; Lehman, "Lutheranism in the Seventeenth Century"; Groen, Terpanggil Untuk Mengakui Iman.

${ }^{17}$ Jan. S. Aritonang, Berbagai Aliran Dalam Dan Sekitar Gereja (Jakarta: BPK Gunung Mulia, 2016), 53-54; Groen, Terpanggil Untuk Mengakui Iman.

${ }^{18}$ Groen, Terpanggil Untuk Mengakui Iman.

${ }^{19}$ Groen.

${ }^{20}$ Naskah ini telah diterjemahkan ke dalam Bahasa Indonesia. Zakharias Ursinus and Caspar Olevian, Pengajaran Agama Kristen: Katekismus Heidelberg, trans. Tim BPK Gunung Mulia (Jakarta: BPK Gunung Mulia, 2000).

${ }^{21}$ Groen, Terpanggil Untuk Mengakui Iman.

${ }^{22}$ Groen.

23 Philip Benedict, "The Second Wave of Protestant Expansion," in The Cambridge History of Christianity: Vol. 6 Reform and Expansion 1500-1660, ed. P. Po-chi Hsia (Cambridge: Cambridge University Press, 2008), 141; Lyle D. Bierma, The Theology of the Heidelberg Catechism: A Reformation Synthesis (Louisville, KY: Columbia Theological Seminary, 2013).

${ }^{24}$ Groen, Terpanggil Untuk Mengakui Iman.

${ }^{25}$ Groen.

${ }^{26}$ Groen.

${ }^{27}$ Groen

${ }^{28}$ Freya Sierhuis, The Literature of the Arminian Controversy: Religion, Politics and the Stage in the Dutch Republic (Oxford: Oxford University Press, 2016), 17-20; Groen, Terpanggil Untuk Mengakui Iman.

${ }^{29}$ Groen, Terpanggil Untuk Mengakui Iman.

30 Theodorus Kobong, Injil Dan Tongkonan: Inkarnasi, Kontekstual, Transformasi, trans. Theodorus Kobong and Thomas van den End (Jakarta: BPK Gunung Mulia, 2008), 264; Thomas van den End, "Christianity in Central and Southern Sulawesi," in A History of Christianity in Indonesia, ed. Jan Sihar Aritonang and Karel Steenbrink, vol. 35 (Leiden: Brill, 2008), 471.

${ }^{31}$ Indu' Yohanes Panggalo, "Pengakuan Gereja Toraja" (Skripsi S.Th., Sekolah Tinggi Theologia Indonesia Timur Makassar, 1981); Kobong, Injil Dan Tongkonan.

32 Andarias Kabanga', Manusia Mati Seutuhnya: Suatu Kajian Antropologi Kristen (Yogyakarta: Media Pressindo, 2002), 242.

${ }^{33}$ Kabanga', Manusia Mati Seutuhnya: Suatu Kajian Antropologi Kristen.

${ }^{34}$ Kabanga'.

${ }^{35}$ Groen, Terpanggil Untuk Mengakui Iman.

${ }^{36}$ Gereja Toraja, Pengakuan Gereja Toraja Dalam Bahasa Indonesia Dan Bahasa Toraja (Rantepao: BPS Gereja Toraja, 1994); Kabanga', Manusia Mati Seutuhnya: Suatu Kajian Antropologi Kristen.

${ }^{37}$ Groen, Terpanggil Untuk Mengakui Iman.

${ }^{38}$ Groen.

${ }^{39}$ Groen.

${ }^{40}$ bdk. Christanto Sema Rappan Paledung, "Partisipasi, Komunitarian, Dan Eskatologi: Sebuah Imajinasi Konstruktif Antara Membali Puang Dan Theōsis," Indonesian Journal of Theology 6, no. 2 (2018): 185-203, https://doi.org/10.46567/ijt.v6i2.12.

${ }^{41}$ Kabanga', Manusia Mati Seutuhnya: Suatu Kajian Antropologi Kristen.

${ }^{42}$ Gereja Toraja, Pengakuan Gereja Toraja.

${ }^{43}$ Kabanga', Manusia Mati Seutuhnya: Suatu Kajian Antropologi Kristen.

${ }^{44}$ Kobong, Injil Dan Tongkonan.

${ }^{45}$ Groen, Terpanggil Untuk Mengakui Iman.

${ }^{46}$ Groen.

${ }^{47}$ Groen.

${ }^{48}$ Groen.

${ }^{49}$ Groen.

${ }^{50}$ Groen.

${ }^{51}$ Groen. 
${ }^{52}$ Heri Lingga, "Ketika GKI Merumuskan Pengakuan Iman Percayanya," Selisip (April) (2014): 22-23; BPMS GKI, Konfesi GKI 2014 (Jakarta: Grafika Kreasindo, 2015); Lihat juga karya Yohanes ABS yang juga membahas Konfesi GKI 2015. Yohanes Augustha Bambang Sethiawan, "Masa Depan Dunia: Sebuah Konstruksi Teologi Tentang Masa Depan Dunia Berdasarkan Analisis Terhadap Konsep Tikkun Olam, Wahyu 21, Dan Konfesi GKI 2014” (Skripsi S.Si.(Teol), Sekolah Tinggi Teologi Jakarta, 2016).

${ }^{53}$ BPMS GKI, Konfesi GKI 2014; Sethiawan, "Masa Depan Dunia."

${ }^{54}$ Groen, Terpanggil Untuk Mengakui Iman.

${ }^{55}$ Groen.

${ }^{56}$ Simon Rae et al., "The Sharp Contrasts of Sumatra," in A History of Christianity in Indonesia, ed. Jan. S. Aritonang and Karel Steenbrink (Leiden: Brill, 2008), 548; Groen, Terpanggil Untuk Mengakui Iman.

57 Jhon P.E. Simorangkir, "Lutheran Identity of Batak Churches: A Study of The Confession of Faith of The HKBP and The Basic Articles of Faith of The GKPI" (D.Th. Dissertation, The Lutheran Theological Seminary Hongkong, 2017), 73.

${ }^{58}$ Groen, Terpanggil Untuk Mengakui Iman; Simorangkir, "Lutheran Identity of Batak Churches."

${ }^{59}$ Groen, Terpanggil Untuk Mengakui Iman.

${ }^{60}$ Groen; Simorangkir, "Lutheran Identity of Batak Churches."

${ }^{61}$ Groen, Terpanggil Untuk Mengakui Iman.

${ }^{62}$ Rae et al., "The Sharp Contrasts of Sumatra."

${ }^{63}$ Groen, Terpanggil Untuk Mengakui Iman.

${ }^{64}$ Rae et al., "The Sharp Contrasts of Sumatra."

${ }^{65}$ Rae et al.; Groen, Terpanggil Untuk Mengakui Iman.

${ }^{66}$ Huria Kristen Batak Protestan, Panindangion Haporseaon Pengakuan Iman The Confession Of Faith (Pearaja: Kantor Pusat HKBP, 2000); Groen, Terpanggil Untuk Mengakui Iman.

${ }^{67}$ Groen, Terpanggil Untuk Mengakui Iman.

${ }^{68}$ Koernia Atje Soejana et al., "Christianity in Javanese Culture and Society," in A History of Christianity in Indonesia, ed. Jan. S. Aritonang and Karel Steenbrink (Leiden: Brill, 2008), 680; Lihat juga uraian lengkap Bambang Subandrijo dan Simon Rachmadi dalam disertasinya. Bambang Subandrijo, "Eikōn and Āyat: Points of Encounter between Indonesian Christian and Muslim Perspectives on Jesus" (Ph.D. Dissertation, Vrije Universiteit, 2007); Simon Rachmadi, "Reformed Spirituality in Java: The Reformed Tradition and the Struggle of the GKJ to Actualize Its Reformed Spirituality in Indonesia" (Ph.D. Dissertation, Vrije Universiteit, 2017); Groen, Terpanggil Untuk Mengakui Iman.

${ }^{69}$ Soejana et al., "Christianity in Javanese Culture and Society."

${ }^{70}$ Groen, Terpanggil Untuk Mengakui Iman.

${ }^{71}$ Groen.

${ }^{72}$ Hadi Purnomo and M. Suprihadi Sastrosupono, Gereja-Gereja Kristen Jawa, GKJ: Benih Yang Tumbuh Dan Berkembang Di Tanah Jawa (Salatiga: Taman Pustaka Kristen, 1988), 51.

${ }^{73}$ Sinode GKJ, Pokok-Pokok Ajaran Gereja Kristen Jawa (Salatiga: Sinode GKJ, 1997), 114.

${ }^{74}$ Sinode GKJ, Pokok-Pokok Ajaran Gereja Kristen Jawa (Salatiga: Sinode GKJ, 2005), 92.

${ }^{75}$ Sinode GKJ, Pokok-Pokok Ajaran Gereja Kristen Jawa, 1997.

${ }^{76}$ Sinode GKJ, Pokok-Pokok Ajaran Gereja Kristen Jawa, 2005.

${ }^{77}$ Rachmadi, "Reformed Spirituality in Java."

78 Jan. S. Aritonang, "The Ecumenical Movement in Indonesia with Special Attention to the National Council of Churches," in A History of Christianity in Indonesia, ed. Jan. S. Aritonang and Karel Steenbrink (Leiden: Brill, 2008), 829; Groen, Terpanggil Untuk Mengakui Iman.

79 Todung Sutan Gunung Mulia memiliki andil besar dalam berdirinya Badan Penerbit Kristen (BPK). Pada tahun 1971, namanya kemudian diabadikan untuk penerbit tersebut, yakni BPK Gunung Mulia. Kees de Jong and Rainy M.P. Hutabarat, "Christian Media," in A History of Christianity in Indonesia, ed. Jan. S. Aritonang and Karel A. Steenbrink (Leiden: Brill, 2008), 968.

${ }^{80}$ Aritonang, "The Ecumenical Movement in Indonesia"; Groen, Terpanggil Untuk Mengakui Iman.

${ }^{81}$ John Mansford Prior and Alle Hoekema, "Theological Thinking by Indonesian Christians, 1850 2000," in A History of Christianity in Indonesia, ed. Jan. S. Aritonang and Karel Steenbrink (Leiden: Brill, 2008), 781; Aritonang, "The Ecumenical Movement in Indonesia."

${ }^{82}$ Aritonang, "The Ecumenical Movement in Indonesia"; Groen, Terpanggil Untuk Mengakui Iman. 


\footnotetext{
${ }^{83}$ Groen, Terpanggil Untuk Mengakui Iman.

${ }^{84}$ Christiaan de Jonge, Apa Itu Calvinisme? (Jakarta: BPK Gunung Mulia, 1995), 83.

${ }^{85}$ Leo J. Koffeman, In Order to Serve: Church Polity in Ecumenical Contexts (Zurich: LIT Verlag Münster, 2014), 16.

${ }^{86}$ Koffeman, In Order to Serve: Church Polity in Ecumenical Contexts.
}

\section{DAFTAR PUSTAKA}

Aritonang, Jan. S. Berbagai Aliran Dalam Dan Sekitar Gereja. Jakarta: BPK Gunung Mulia, 2016.

- "The Ecumenical Movement in Indonesia with Special Attention to the National Council of Churches." In A History of Christianity in Indonesia, edited by Jan. S. Aritonang and Karel Steenbrink, 823-66. Leiden: Brill, 2008. Benedict, Philip. "The Second Wave of Protestant Expansion." In The Cambridge History of Christianity: Vol. 6 Reform and Expansion 1500-1660, edited by P. Po-chi Hsia, 125-44. Cambridge: Cambridge University Press, 2008.

Bierma, Lyle D. The Theology of the Heidelberg Catechism: A Reformation Synthesis. Louisville, KY: Columbia Theological Seminary, 2013.

BPMS GKI. Konfesi GKI 2014. Jakarta: Grafika Kreasindo, 2015.

Drewes, B F, and Julianus Mojau. Apa Itu Teologi?: Pengantar Ke Dalam Ilmu Teologi. BPK Gunung Mulia, 2003.

End, Thomas van den. "Christianity in Central and Southern Sulawesi." In A History of Christianity in Indonesia, edited by Jan Sihar Aritonang and Karel Steenbrink, 35:455-92. Leiden: Brill, 2008.

— - ed. Enam Belas Dokumen Dasar Calvinisme. Jakarta: BPK Gunung Mulia, 2004.

Forell, George W. The Augsburg Confession: A Contemporary Commentary. Minneapolis, MN: Augsburg Publishing House, 1968.

Gereja Toraja. Pengakuan Gereja Toraja Dalam Bahasa Indonesia Dan Bahasa Toraja. Rantepao: BPS Gereja Toraja, 1994.

Groen, Jacob P. D. Terpanggil Untuk Mengakui Iman: Pembimbing Ke Dalam Dokumen-Dokumen Pengakuan Gereja. Edited by Widyowati Purwanto and 
Chrisostomus Sihotang. Jakarta: BPK Gunung Mulia, 2012.

Huria Kristen Batak Protestan. Panindangion Haporseaon Pengakuan Iman The Confession Of Faith. Pearaja: Kantor Pusat HKBP, 2000.

Jonar, Radius Aditiya. “Teologis Atau Politis?: Pencarian Makna Pergulatan Historis Dalam Pengakuan Iman Nicea-Konstantinopel.” Jurnal Theologia in Loco 2, no. 1 (2020): 48-71.

Jong, Kees de, and Rainy M.P. Hutabarat. "Christian Media." In A History of Christianity in Indonesia, edited by Jan. S. Aritonang and Karel A. Steenbrink, 951-75. Leiden: Brill, 2008.

Jonge, Christiaan de. Apa Itu Calvinisme? Jakarta: BPK Gunung Mulia, 1995.

. Gereja Mencari Jawab: Kapita Selekta Sejarah Gereja. Jakarta: BPK Gunung Mulia, 2003.

Kabanga', Andarias. Manusia Mati Seutuhnya: Suatu Kajian Antropologi Kristen. Yogyakarta: Media Pressindo, 2002.

Kobong, Theodorus. Injil Dan Tongkonan: Inkarnasi, Kontekstual, Transformasi. Translated by Theodorus Kobong and Thomas van den End. Jakarta: BPK Gunung Mulia, 2008.

Koffeman, Leo J. In Order to Serve: Church Polity in Ecumenical Contexts. Zurich: LIT Verlag Münster, 2014.

Lehman, Hartmut. "Lutheranism in the Seventeenth Century." In The Cambridge History of Christianity: Vol. 6 Reform and Expansion 1500-1660, edited by R. Po-chia Hsia. Cambridge: Cambridge University Press, 2008.

Lingga, Heri. "Ketika GKI Merumuskan Pengakuan Iman Percayanya.” Selisip (April) (2014): 22-23.

Paledung, Christanto Sema Rappan. "Partisipasi, Komunitarian, Dan Eskatologi: Sebuah Imajinasi Konstruktif Antara Membali Puang Dan Theōsis." Indonesian Journal of Theology 6, no. 2 (2018): 185-203. https://doi.org/10.46567/ijt.v6i2.12.

Panggalo, Indu' Yohanes. "Pengakuan Gereja Toraja.” Skripsi S.Th., Sekolah Tinggi Theologia Indonesia Timur Makassar, 1981.

Prior, John Mansford, and Alle Hoekema. "Theological Thinking by Indonesian 
Christians, 1850-2000." In A History of Christianity in Indonesia, edited by Jan. S. Aritonang and Karel Steenbrink, 749-822. Leiden: Brill, 2008.

Purnomo, Hadi, and M. Suprihadi Sastrosupono. Gereja-Gereja Kristen Jawa, GKJ: Benih Yang Tumbuh Dan Berkembang Di Tanah Jawa. Salatiga: Taman Pustaka Kristen, 1988.

Rachmadi, Simon. "Reformed Spirituality in Java: The Reformed Tradition and the Struggle of the GKJ to Actualize Its Reformed Spirituality in Indonesia." Ph.D. Dissertation, Vrije Universiteit, 2017.

Rae, Simon, Jan S. Aritonang, Richard Daulay, E. Hoogerwerf, and Uwe Hummel. "The Sharp Contrasts of Sumatra." In A History of Christianity in Indonesia, edited by Jan. S. Aritonang and Karel Steenbrink, 527-637. Leiden: Brill, 2008 .

Sethiawan, Yohanes Augustha Bambang. "Masa Depan Dunia: Sebuah Konstruksi Teologi Tentang Masa Depan Dunia Berdasarkan Analisis Terhadap Konsep Tikkun Olam, Wahyu 21, Dan Konfesi GKI 2014.” Skripsi S.Si.(Teol), Sekolah Tinggi Teologi Jakarta, 2016.

Sierhuis, Freya. The Literature of the Arminian Controversy: Religion, Politics and the Stage in the Dutch Republic. Oxford: Oxford University Press, 2016.

Simorangkir, Jhon P.E. "Lutheran Identity of Batak Churches: A Study of The Confession of Faith of The HKBP and The Basic Articles of Faith of The GKPI.” D.Th. Dissertation, The Lutheran Theological Seminary Hongkong, 2017.

Sinode GKJ. Pokok-Pokok Ajaran Gereja Kristen Jawa. Salatiga: Sinode GKJ, 1997.

—. Pokok-Pokok Ajaran Gereja Kristen Jawa. Salatiga: Sinode GKJ, 2005.

Soejana, Koernia Atje, Budi Subanar, Alle G. Hoekema, Raymundus I Made Sudhiarsa, and Karel A. Steenbrink. "Christianity in Javanese Culture and Society.” In A History of Christianity in Indonesia, edited by Jan. S. Aritonang and Karel Steenbrink, 639-729. Leiden: Brill, 2008.

Subandrijo, Bambang. "Eikōn and Āyat: Points of Encounter between Indonesian Christian and Muslim Perspectives on Jesus." Ph.D. Dissertation, Vrije Universiteit, 2007. 
Tappert, Theodore G., and Mangisi S.E. Simorangkir, eds. Buku Konkord: Konfesi Gereja Lutheran. Jakarta: BPK-Gunung Mulia, 2004.

Timo, Ebenhaizer Nuban. “Gereja Merumuskan Jawaban: Sebuah Bentuk Pengakuan Iman Kontemporer Di NTT.” BERBAGI: Jurnal Asosiasi Perguruan Tinggi Katolik 3, no. 2 (2014): 217-48.

Ursinus, Zakharias, and Caspar Olevian. Pengajaran Agama Kristen: Katekismus Heidelberg. Translated by Tim BPK Gunung Mulia. Jakarta: BPK Gunung Mulia, 2000.

Williamson, G. I. The Heidelberg Catechism. P\&R Publishing, 1993. 